\title{
Microbiological assessment of the indoor air quality of a university health centre in Nigeria
}

\author{
OO Ayepola*, LO Egwari, Gl Olasehinde \\ From 3rd International Conference on Prevention and Infection Control (ICPIC 2015) \\ Geneva, Switzerland. 16-19 June 2015
}

\section{Introduction}

The air within the healthcare environment may serve as a reservoir for microorganisms thereby contributing to the rate of infection. Regular monitoring of the microbial burden is necessary to ascertain the microbiological quality of hospital environments.

\section{Objectives}

This study was conducted to evaluate the quality of the indoor air in a university health centre.

\section{Methods}

The air microflora was assessed using the settle plate method. Air samples were taken from the waiting room, consulting rooms, nurse station, male and female wards as well as the laboratory to detect bacterial and fungal flora. The antimicrobial activity of five commonly used disinfectants was tested on some of the isolated bacteria.

\section{Results}

Thirteen bacterial genera and two fungal genera were identified. The predominant bacteria were Klebsiella spp (15.7\%), Bacillus spp (15.7\%) and Streptococcus spp (10.5\%). Among the less common bacterial isolates were Staphylococcus aureus and Clostridium spp. The fungal isolates include Aspergillus niger (50\%) and Mucor spp (50\%). The microbial burden was highest in the wards, followed by the consulting rooms and the waiting room. The antimicrobial activity the disinfectants varied with the concentrations tested. Klebsiella species were resistant to two of these disinfectants at all concentrations.

\section{Conclusion}

The findings of this study revealed the presence of possible pathogens. This emphasizes the importance of

Biological Sciences, Covenant University, Ota, Nigeria regular air surveillance and proper infection control practices in hospitals.

\section{Disclosure of interest}

None declared.

Published: 16 June 2015

\section{doi:10.1186/2047-2994-4-S1-P51}

Cite this article as: Ayepola et al:: Microbiological assessment of the indoor air quality of a university health centre in Nigeria. Antimicrobial Resistance and Infection Control 2015 4(Suppl 1):P51.

\section{Submit your next manuscript to BioMed Central and take full advantage of: \\ - Convenient online submission \\ - Thorough peer review \\ - No space constraints or color figure charges \\ - Immediate publication on acceptance \\ - Inclusion in PubMed, CAS, Scopus and Google Scholar \\ - Research which is freely available for redistribution

